Brit. J. industr. Med., 1965, 22, 27.

\title{
BYSSINOSIS AND OTHER RESPIRATORY SYMPTOMS IN FLAX WORKERS IN NORTHERN IRELAND
}

\author{
BY \\ P. C. ElWOOD*, J. PEMberton, J. D. MERRETT, G. C. R. CAREY, and I. R. McAulay \\ From the Department of Social and Preventive Medicine, The Queen's University of Belfast
}

(RECEIVED FOR PUBLICATION JUNE 3, 1964)

\begin{abstract}
A study of byssinosis and other respiratory symptoms in 2,528 flax workers aged 35 years and over in Northern Ireland is reported. This represented $82.5 \%$ of the total available population. Only $3 \%$ of workers were not seen because of absence or a refusal to co-operate. Workers were interviewed using a questionnaire based on the Questionnaire on Respiratory Symptoms (Medical Research Council, 1960a) with additional questions relating to respiratory symptoms at work. Byssinosis was found in workers in all stages of the industry, though its prevalence was highest in flax preparers; wet spinners and wet polishers did not appear to be at serious risk of developing the condition. When the effects of other relevant factors had been allowed for, e.g., age, duration of employment, and smoking habits, differences between the prevalence in the two sexes were found to be very small. The associations between byssinosis and the age of workers and their durations of employment in flax-preparing occupations were complex, and it was thought that a selective discharge of affected workers before the study might, in part at least, explain the absence of marked associations between these variables.

Marked associations were found between both chronic bronchitis and exertional dyspnoea and the type of occupation in the mill. Workers in the early preparing occupations had a considerably higher prevalence of these conditions than expected on a null hypothesis. There were also marked associations between byssinosis and bronchitis, and between byssinosis and dyspnoea. The possible importance of these associations with regard to the aetiology of byssinosis is discussed, and it is suggested that byssinosis represents an acute, specific effect of certain textile dusts on the respiratory system, superimposed on a non-specific chronic bronchitic process.
\end{abstract}

Respiratory symptoms have long been known to occur in workers handling flax (Ramazzini, 1705; Thackrah, 1832; Malcolm, 1856; Purdon, 1873, 1875 , and 1877), and recent reports have confirmed that byssinosis occurs among them (Smiley, 1951 and 1961; Logan, 1959; Mair, Smith, Wilson, and Lockhart, 1960; Bouhuys, Van Duyn, and Van Lennep, 1961).

The following is a report of a survey of byssinosis and other respiratory symptoms in the flax-spinning industry in Northern Ireland in 1961-62. The survey formed part of a larger enquiry which included the measurement of the respiratory function of workers (Carey, Merrett, Elwood, Pemberton, and McAulay, 1965), the levels of airborne dust in their working environment (McAulay, Carey, Merrett, Elwood,

*Now at the Medical Research Council Epidemiological Research Unit, South Wales. and Pemberton, 1965), the prevalence of byssinosis in relation to dust levels (Elwood and McAulay, 1965), and a follow-up study of discharged workers (Elwood, 1965).

\section{The Preparation and Spinning of Flax}

The manufacture of yarns from raw flax differs only in certain processes from that of cotton and other natural fibres. The 'ultimate fibres' in the flax plant are about $1 \frac{1}{4}$ in. $(31.75 \mathrm{~mm}$.) long, but these, as they occur naturally, are bound together into 'compound fibres' which run the full length of the plant stem and are joined to each other at intervals. These compound fibres are separated from the woody part of the stem by beating (scutching) bundles of the plants after they have been softened by bacteria during submersion in water (water retting), or by 
FLAX PREPARING AND SPINNING

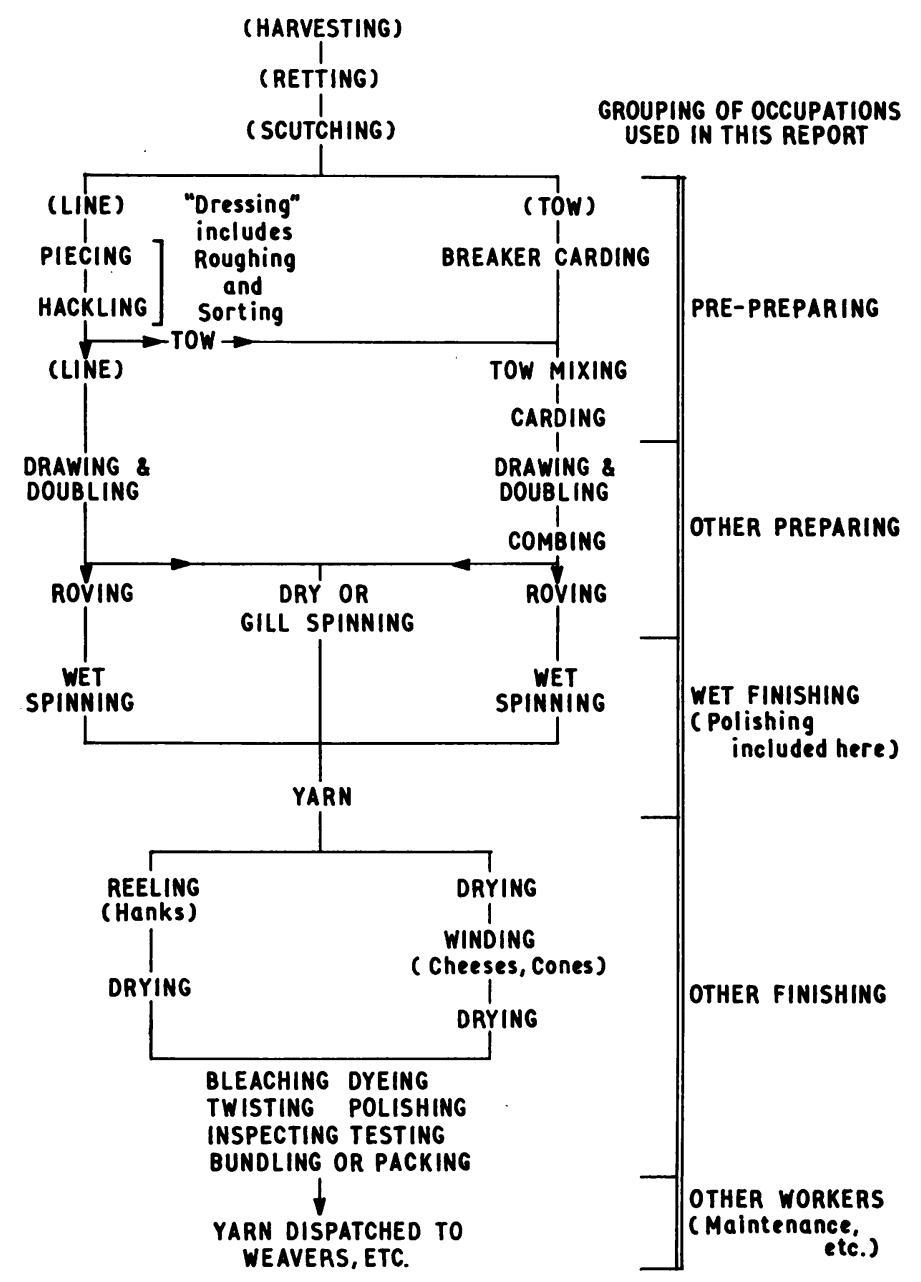

moulds and fungi when spread on the open ground (dew retting), or occasionally by chemical means (tank retting). Almost no flax is grown in Northern Ireland now, and that which is imported arrives at the mills already retted and scutched.

The processes in the mill have been grouped under five broad occupational headings in order to analyse the prevalence of byssinosis and other respiratory symptoms by occupation. The groups are as follows: pre-preparers, other preparers, wet finishers, other finishers and all other workers (maintenance men, electricians, etc.). This grouping and the sequence of processes in the production of yarn from flax is shown above. Bundles of flax are first combed (hackled) to separate the compound fibres and to remove dirt and plant debris and separate out the short fibres or 'tow'. The tow is carded to produce a clean, loosely matted ribbon or 'sliver', but bundles of hackled flax or 'line' have to be laid end to end to form a continuous sliver. The slivers are drawn out and doubled repeatedly and, because of the length of the fibres, control of the sliver during drawing is achieved by passing it through rows of pins or 'gills', and not, as in cotton-drawing frames, through parallel pressure rollers.

The spinning of coarse yarns from flax is similar to the spinning of cotton yarns, but to enable the sliver of flax to be drawn out sufficiently to give fine yarns, the gums, which bind the ultimate fibres together, have to be softened in hot water (wet 
spinning). Some coarse yarns, however, are spun dry, and the slivers for these receive their final drawing on a spinning frame, which is very similar to a roving frame as used in cotton preparing, though sometimes such dry spun yarn is passed over a damp roller to smooth down protruding fibres ('gill' spinning). Dry (or gill) spinning can probably therefore best be considered as a modified preparing process rather than as a non-preparing process.

In what follows, pre-preparers and other preparers may be referred to together as preparers, and wet finishers, other finishers, and all other workers may be referred to as non-preparers.

\section{Method}

Procedure.-An attempt was made to interview all workers, aged 35 years or more, in all Northern Ireland mills who were known to be processing flax at the time of the study. Interviews were conducted on Wednesdays, Thursdays, and occasionally on Tuesdays in the welfare or medical department of each mill, and the order in which workers attended was decided by the management. A small number of workers who were absent during the survey or who refused to attend for interview were later interviewed in their work-rooms.

Each worker was asked questions about respiratory symptoms based on those of the Questionnaire on Respiratory Symptoms (Medical Research Council, 1960a), and questions about respiratory symptoms related to the time of onset, which closely followed the questions used in the cotton industry by Schilling (1960, and personal communication). Questions about tobacco consumption (Medical Research Council, 1960a) were also asked. These interviews were all conducted by one observer (P.C.E.) to whom the occupation of each worker was unknown, though some workers inadvertently betrayed their job or place of work by their dress or conversation. Details of occupation in the mill, and in particular the duration of employment in flax preparing, were obtained by a subsequent interviewer (G.C.R.C.), who also carried out respiratory function tests. The results of the latter are reported elsewhere (Carey et al., 1965).

Definitions.-For each worker interviewed, details of sex, age, smoking habit, occupation group, and duration of employment in flax-preparing processes were available for analysis in addition to the clinical data. In the analysis, four age groups have been used; 35-44, 45-54, 55-64, and $65+$ for men, and 35-44, 45-54, 55-59, and $60+$ for women. The slightly different grouping for the two sexes was adopted to take account of the different statutory retiring ages for male and female workers. Three smoking habit categories have been used, non-smoker, smoker, and ex-smoker; a smoker was one who had smoked at least one cigarette or $1 \mathrm{~g}$. of tobacco each day for at least the past year, and an ex-smoker was a worker who, having been a smoker, had not smoked as much as one cigarette a day, or its equivalent, for at least the immediately preceding three months. A non-smoker was one who had never smoked as much as one cigarette, or its equivalent, a day for as long as one year.

Mills were divided into those in which flax only was processed and those in which flax and synthetic fibres, but no other natural fibres, were processed.

Occupations in the mills were grouped under five broad headings as mentioned above (see p. 28). For some analyses 'pre-preparers' and 'other preparers' have been grouped together as 'preparers', and 'wet finishers', 'other finishers', and 'other workers' have been grouped together as 'non-preparers'.

Symptoms of chronic bronchitis were graded at three levels, based on the grading of phlegm and previous chest illness as suggested in the Instructions for the use of the Questionnaire on Respiratory Symptoms (Medical Research Council, 1960b). They are therefore similar to those used by several recent writers (Fletcher and Tinker, 1961; Higgins and Cochrane, 1961). These grades are as follows:

Grade $\mathrm{O}$, no chronic bronchitis. No evidence of the production of phlegm from the chest of sufficient severity to be graded below.

Grade S, simple chronic bronchitis. Evidence of the production of phlegm from the chest first thing in the morning and/or during the day and/or night on most days for a period of at least three months each year, for at least the past two years, without a recent exacerbation as described below.

Grade E, chronic bronchitis with an exacerbation. Evidence of the presence of simple chronic bronchitis as defined above but including a period of increased production of phlegm lasting three weeks or more within the last three years, and/or a chest illness with an increased production of phlegm causing an absence from work for at least one week within the last three years.

Exertional dyspnoea was graded as suggested in the same instructions (Medical Research Council, 1960b) as follows:

Grade I: No evidence of dyspnoea when hurrying on the level or walking up a slight incline.

Grade II: Evidence of dyspnoea when hurrying on the level and/or walking up a slight incline but not when walking at an ordinary speed on the level.

Grade III: Evidence of dyspnoea when walking at an ordinary speed on the level.

In this paper the more severe grades, IV and V, as used by the Medical Research Council (1960b) are grouped with grade III.

Workers who answered 'yes' to the question 'Have you ever had heart trouble?', together with those who were seen to be physically disabled from walking from other than respiratory causes, were omitted from all analyses of this symptom.

Symptoms of byssinosis were graded at four levels, which closely follow those used by Roach and Schilling (1960).

Grade 0: No evidence of breathlessness or chest tightness or discomfort of the chest on Mondays, nor of cough or wheezing which is worse on Mondays than on other days.

Grade $\frac{1}{2}$ : Evidence of breathlessness and/or chest tightness and/or discomfort of the chest on some Mondays, 
and/or cough or wheezing which is always worse on Mondays than on other days.

Grade I: Evidence of breathlessness and/or chest tightness on every Monday but not on other days.

Grade II: Evidence of breathlessness and/or chest tightness and/or discomfort of the chest on every Monday and also on some other days, provided that at one time in the past symptoms were confined to Monday.

'Monday' is used to imply the working hours, or the period immediately following (i.e., the period spent travelling home from work), during the first day of each working week.

An attempt was made to allow for possible effects of air pollution by grouping workers into those who worked in town mills (mills situated in urban areas with a population of 5,000 or more) and those who worked in country mills (all other mills) at the time of interview.

Method of Analysis.-The analysis was based on comparisons of the observed distributions of workers with those expected on the hypothesis that the distribution of workers by a symptom (usually a byssinosis grade) is the same in groups of workers defined by a factor, such as occupation or smoking habit, when the other factors relevant to the distribution of the symptom are held constant. These factors are, in addition to occupation and smoking habit, age, location of mill (town or country), and, in certain analyses, duration of employment in preparing processes in the flax industry. The suitability of using this null hypothesis in this context is discussed later.

In the analysis of the association between the symptoms and each factor of interest, other relevant factors were held constant by a process of standardization of the expected distributions. For example, in the analysis of the association between byssinosis and occupation this was as follows. Within each sex separately the population was subdivided by age, smoking habit, and location of the mill. Within each resultant sub-group the prevalence of each grade of byssinosis was calculated, and these rates were applied to the total numbers of workers in each of the five occupational categories within that subgroup to yield expected numbers of workers with each grade of byssinosis. Provided that within the separate sub-groups the trends shown by the differences between the observed and expected distributions were reasonably consistent, the expected numbers were summed over all sub-groups, within each occupational group separately, to yield total expected distributions for each occupational group. These distributions, which are those that would be expected had occupation in the mill no association with byssinosis grade, and which have been standardized to allow for the independent effects of age, smoking habit, and the area of the mill, can be compared with the distributions observed.

The significance of the discrepancies between an observed distribution and an expected distribution which has been standardized in this way cannot be easily assessed. A measure of the total discrepancy can be obtained by the calculation of an index similar to $\chi^{2}$, that is the sum of the ratios of the squared deviations to the expectations, but the distribution of this index is not known and it does not appear to be identical with that of $\chi^{2}$. However, the differences between it and $\chi^{2}$ are assumed to be small, and it is stated here as $\chi^{2}$, and the probabilities quoted for it are those for $\chi^{2}$. Probabilities less than 0.05 are accepted as significant in what follows, but the results of these tests must be interpreted with caution.

\section{Results}

Population Studied.-There were 20 mills in Northern Ireland at the time of the study which were known to be preparing and spinning flax. Eight of these handled synthetic fibres in addition to flax. One mill (flax only) had to be omitted as the management felt unable to co-operate, and in one mill (flax plus synthetic) certain sections had to be omitted owing to reorganization of workers and machines. Maintenance workers were not seen in the first two mills visited, and though a small number of night workers in several mills were seen, all night workers are for convenience considered as omissions. Ninetyone workers were not seen because of absence from the mill or refusal to co-operate (Table 1). The sex,

\section{TABLE 1}

DISTRIBUTION OF WORKERS OVER 35 YEARS OF AGE IN FLAX AND FLAX AND SYNTHETIC MILLS IN NORTHERN IRELAND, BY SEX (WHERE AVAILABLE), WHETHER OR NOT INTERVIEWED, AND REASON FOR OMISSION

\begin{tabular}{l|c|r|rr}
\hline & Male & Female & \multicolumn{2}{|c}{ Totals } \\
\cline { 2 - 4 } $\begin{array}{l}\text { Workers interviewed in 19 } \\
\text { mills }\end{array}$ & 856 & 1,672 & 2,528 & $(82.5 \%)$ \\
\hline $\begin{array}{l}\text { Workers not interviewed } \\
\text { Absentees and refusals } \\
\text { in 19 mills }\end{array}$ & 32 & 59 & 91 & $(3.0 \%)$ \\
$\begin{array}{l}\text { Night workers in 19 } \\
\text { mills } \\
\text { Maintenance workers in } \\
\text { two mills }\end{array}$ & 37 & 170 & 207 & $(6.7 \%)$ \\
$\begin{array}{l}\text { Mill omitted } \\
\text { Mill partially omitted }\end{array}$ & $40^{*}$ & - & $\left.\begin{array}{r}40^{*} \\
150^{*} \\
50^{*}\end{array}\right\}(7.8 \%)$ \\
\hline Total & & & $3,066^{*}(100 \%)$ \\
\hline
\end{tabular}

*Estimated numbers.

age, and occupation are known for these but not for other omissions. On inspection it appeared that they had occurred in most age and occupation sub-groups and not predominantly in one or in a few such sub-groups.

The total number of workers aged 35 years and over interviewed was 2,528, and this represents $82.5 \%$ of the estimated total number of all workers aged 35 years or more in flax mills in Northern Ireland. However, in the 19 mills visited and excluding those sections of the mill which were only partially surveyed, only $3.0 \%$ of workers were not seen because of absence or refusal to co-operate. The following discussion relates to the 2,528 workers interviewed. 
Byssinosis and Type and Location of Mill.--In workers of each sex, the effect of the type of mill (flax only or flax plus synthetic) and location of the mill (town or country) on the distribution of byssinosis within each occupation group, independent of the effects of age and smoking habit, was first examined. In both sexes the differences in the prevalence of byssinosis in mills of the two types (flax only or flax plus synthetic) were small, as were the differences in the prevalence of byssinosis in the town and country mills, and none of these differences if tested by $\chi^{2}$ are significant. Among women nonpreparers in the town flax mills, the prevalence of byssinosis was slightly higher than in the country mills, and the differences appear to be significant. The factor 'type of mill' has therefore been ignored throughout in what follows, and mills of both types are referred to as 'flax mills'. Expected distributions have, however, except where mentioned, been standardized for the location of the mill.

Byssinosis and Occupation Group.-The effect of the type of occupation in the mill on the prevalence of byssinosis is shown for male and female workers in Tables 2 and 3 respectively. In each sex the observed numbers of workers with byssinosis in preparing processes greatly exceed those expected, whereas the observed numbers with byssinosis in non-preparing processes are considerably smaller than those expected on the null hypothesis, and these differences appear to be significant.

Among the 205 workers in pre-preparing rooms there were 111 cases of byssinosis; among the 737 workers in other preparing rooms there were 196 cases; among the 708 workers in other finishing

\section{TABLE 2}

OBSERVED DISTRIBUTION OF MALE WORKERS BY BYSSINOSIS GRADE AND OCCUPATION GROUP, AND THAT EXPECTED ON THE BASIS OF A NULL HYPOTHESIS AFTER STANDARDIZATION FOR AGE, SMOKING HABIT, AND LOCATION OF MILL

\begin{tabular}{|c|c|c|c|c|c|c|}
\hline \multirow{2}{*}{\multicolumn{2}{|c|}{ Occupation Group }} & \multicolumn{4}{|c|}{ Byssinosis Grade } & \multirow{3}{*}{$\begin{array}{l}\text { Totals } \\
159 \\
159.0\end{array}$} \\
\hline & & \multirow{2}{*}{$\begin{array}{c}0 \\
71 \\
130.0\end{array}$} & \multirow{2}{*}{$\begin{array}{l}\frac{1}{2} \\
28 \\
12 \cdot 3\end{array}$} & \multirow{2}{*}{$\begin{array}{c}I \\
27 \\
8.6\end{array}$} & \multirow{2}{*}{ 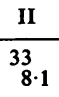 } & \\
\hline Pre-preparers & $\begin{array}{l}\text { Observed } \\
\text { Expected }\end{array}$ & & & & & \\
\hline Other preparers & $\begin{array}{l}\text { Obse } \\
\text { Expe }\end{array}$ & $\begin{array}{l}66 \\
84.6\end{array}$ & $\begin{array}{l}19 \\
8 \cdot 2\end{array}$ & $\begin{array}{c}13 \\
5.4\end{array}$ & $\begin{array}{l}5 \\
4.8\end{array}$ & $\begin{array}{l}103 \\
103 \cdot 0\end{array}$ \\
\hline Wet finishers & $\begin{array}{l}\text { Observe } \\
\text { Expecte }\end{array}$ & $\begin{array}{l}57 \\
48 \cdot 3 \\
\end{array}$ & $\begin{array}{l}1 \\
4 \cdot 1 \\
\end{array}$ & $\overline{2.9}$ & $\overline{2 \cdot 7}$ & $\begin{array}{l}58 \\
58.0 \\
\end{array}$ \\
\hline Other finishers & $\begin{array}{l}\text { Observ } \\
\text { Expect }\end{array}$ & $\begin{array}{l}141 \\
120 \cdot 3\end{array}$ & $\stackrel{2}{11 \cdot 2}$ & 2 & $\overline{6 \cdot 2}$ & $\begin{array}{l}145 \\
145.0 \\
\end{array}$ \\
\hline & & $\begin{array}{l}373 \\
324 \cdot 8\end{array}$ & $\begin{array}{l}15 \\
29 \cdot 2\end{array}$ & $\begin{array}{c}1 \\
18 \cdot 8\end{array}$ & $\begin{array}{c}2 \\
18 \cdot 2\end{array}$ & $\begin{array}{l}391 \\
391 \cdot 0\end{array}$ \\
\hline
\end{tabular}

Wet finishers and other finishers grouped for $\chi^{2}$ test: Total $x^{2}=$ 190.78; D.F. $=9$; P $<0.001$.

N.B.-The validity of the $x^{2}$ test in this and subsequent tables is discussed in the text.
TABLE 3

OBSERVED DISTRIBUTION OF FEMALE WORKERS BY BYSSINOSIS GRADE AND OCCUPATION GROUP, AND THAT EXPECTED ON THE BASIS OF A NULL HYPOTHESIS, AFTER STANDARDIZATION FOR AGE, SMOKING HABIT, AND LOCATION OF MILL

\begin{tabular}{|c|c|c|c|c|c|c|}
\hline \multirow{2}{*}{\multicolumn{2}{|c|}{ Occupation Group }} & \multicolumn{4}{|c|}{ Byssinosis Grade } & \multirow{3}{*}{$\begin{array}{c}\text { Totals } \\
\begin{array}{c}46 \\
46.0\end{array}\end{array}$} \\
\hline & & \multirow{2}{*}{$\begin{array}{c}0 \\
23 \\
40 \cdot 2\end{array}$} & \multirow{2}{*}{$\begin{array}{l}\frac{1}{2} \\
7 \\
2 \cdot 7\end{array}$} & \multirow{2}{*}{$\frac{I}{11}$} & \multirow{2}{*}{$\begin{array}{l}\text { II } \\
5 \\
1 \cdot 1\end{array}$} & \\
\hline Pre-preparers & $\begin{array}{l}\text { Observed } \\
\text { Expected }\end{array}$ & & & & & \\
\hline Other $\mathrm{p}$ & & $\begin{array}{l}475 \\
562 \cdot 5\end{array}$ & $\begin{array}{l}74 \\
31 \cdot 7\end{array}$ & $\begin{array}{l}53 \\
26 \cdot 6\end{array}$ & $\begin{array}{l}32 \\
14 \cdot 2\end{array}$ & $\begin{array}{l}634 \\
634.0 \\
\end{array}$ \\
\hline Wet finishers & $\begin{array}{l}\text { Observed } \\
\text { Expected }\end{array}$ & 394 & $22 \cdot 2$ & $\overline{17 \cdot 5}$ & $\overline{9 \cdot 7}$ & $\begin{array}{l}395 \\
395.0\end{array}$ \\
\hline Other finishers & $\begin{array}{l}\text { Observ } \\
\text { Expect }\end{array}$ & \begin{tabular}{l|}
554 \\
$501 \cdot 1$
\end{tabular} & $\begin{array}{c}4 \\
27 \cdot 9\end{array}$ & $\stackrel{4}{21 \cdot 7}$ & $\begin{array}{c}1 \\
12 \cdot 3\end{array}$ & $\begin{array}{l}563 \\
563.0 \\
\end{array}$ \\
\hline th & & $\begin{array}{l}34 \\
30 \cdot 6\end{array}$ & $\overline{1 \cdot 6}$ & $\overline{1 \cdot 1}$ & $\overline{0.7}$ & $\begin{array}{l}34 \\
34 \cdot 0\end{array}$ \\
\hline
\end{tabular}

Pre-preparers and other preparers, and other finishers and other workers grouped for $x^{2}$ test: Total $x^{2}=268.87$; D.F. $=6$; P $<0.001$.

rooms there were 13 cases; and among the 453 wet finishers there were two cases, both grade $\frac{1}{2}$ byssinosis.

Chronic Bronchitis and Occupation Group.Tables 4 and 5 show that in both sexes there is, independent of the effects of age, smoking habit, and the location of the mill, a marked association between the distributions of workers by chronic bronchitis grade and occupation group. The prevalence of these symptoms is higher in workers in preparing departments and lower in workers in non-preparing departments than expected on the null hypothesis. These differences are large and are probably significant.

Dyspnoea and Occupation Group.-In both sexes there is a marked association between the distributions of workers by dyspnoea grade and occupation group (Tables 6 and 7). Workers in preparing departments have a much higher prevalence of dyspnoea and workers in non-preparing departments a much lower prevalence than expected on the null hypothesis, and the differences appear to be significant.

Byssinosis and Age.-In the examination of the association between byssinosis and age, the length of time spent in flax-preparing occupations is relevant. Workers were therefore divided into four groups-those who had spent under 15 years, 15 to 24 years, 25 to 34 years, and 35 years or more in preparing occupations in flax mills, and expected distributions were standardized for this factor in addition to smoking habit. To avoid the possible effects of selection of workers at ages above the 
TABLE 4

OBSERVED DISTRIBUTION OF MALE WORKERS BY CHRONIC BRONCHITIS GRADE AND OCCUPATION GROUP, AND THAT EXPECTED ON THE BASIS OF A NULL HYPOTHESIS, AFTER STANDARDIZATION FOR AGE, SMOKING HABIT, AND LOCATION OF MILL

\begin{tabular}{|c|c|c|c|c|c|}
\hline \multirow{2}{*}{\multicolumn{2}{|c|}{ Occupation Group }} & \multicolumn{3}{|c|}{ Chronic Bronchitis Grade* } & \multirow{3}{*}{$\begin{array}{l}\text { Totals } \\
\begin{array}{l}159 \\
159.0\end{array}\end{array}$} \\
\hline & & \multirow{2}{*}{$\begin{array}{c}0 \\
\begin{array}{c}99 \\
117.5\end{array}\end{array}$} & \multirow{2}{*}{\begin{tabular}{l}
\multicolumn{1}{c}{$S$} \\
35 \\
$28 \cdot 3$
\end{tabular}} & \multirow{2}{*}{$\begin{array}{l}E \\
25 \\
13 \cdot 2\end{array}$} & \\
\hline Pre-preparers & $\begin{array}{l}\text { Observed } \\
\text { Expected }\end{array}$ & & & & \\
\hline Other preparers & $\begin{array}{l}\text { Observed } \\
\text { Expected }\end{array}$ & $\begin{array}{l}74 \\
76 \cdot 5\end{array}$ & $\begin{array}{l}21 \\
18 \cdot 2\end{array}$ & $\begin{array}{l}8 \\
8 \cdot 3\end{array}$ & $\begin{array}{l}103 \\
103.0\end{array}$ \\
\hline Wet finishers & $\begin{array}{l}\text { Observed } \\
\text { Expected }\end{array}$ & $\begin{array}{l}50 \\
44 \cdot 3\end{array}$ & $\begin{array}{l}5 \\
9.5\end{array}$ & $\begin{array}{l}3 \\
4 \cdot 2\end{array}$ & $\begin{array}{l}58 \\
58.0\end{array}$ \\
\hline Other finishers & $\begin{array}{l}\text { Observed } \\
\text { Expected }\end{array}$ & $\begin{array}{l}115 \\
108.6\end{array}$ & $\begin{array}{l}22 \\
26.4\end{array}$ & $\begin{array}{c}8 \\
10 \cdot 0\end{array}$ & $\begin{array}{l}145 \\
145.0\end{array}$ \\
\hline Other $v$ & $\begin{array}{l}\text { Observed } \\
\text { Expected }\end{array}$ & $\begin{array}{l}301 \\
292 \cdot 2\end{array}$ & $\begin{array}{l}68 \\
69 \cdot 5\end{array}$ & $\begin{array}{l}22 \\
29 \cdot 3\end{array}$ & $\begin{array}{l}391 \\
391.0\end{array}$ \\
\hline
\end{tabular}

${ }^{*} \mathrm{O}=$ no chronic bronchitis; $\mathrm{S}=$ simple; $\mathrm{E}=$ with an exacerbation (see text).

Wet finishers and other finishers grouped for $\chi^{2}$ test: $\chi^{2}=21.98$; D.F. $=6 ; 0.01>P>0.001$.

TABLE 5

OBSERVED DISTRIBUTION OF FEMALE WORKERS BY CHRONIC BRONCHITIS GRADE AND OCCUPATION GROUP, AND THAT EXPECTED ON THE BASIS OF A NULL HYPOTHESIS, AFTER STANDARDIZATION FOR AGE, SMOKING HABIT, AND LOCATION OF MILL

\begin{tabular}{|c|c|c|c|c|c|}
\hline \multirow{2}{*}{\multicolumn{2}{|c|}{ Occupation Group }} & \multicolumn{3}{|c|}{ Chronic Bronchitis Grade* } & \multirow{3}{*}{$\begin{array}{c}\text { Totals } \\
46 \\
46 \cdot 0\end{array}$} \\
\hline & & \multirow{2}{*}{$\begin{array}{l}0 \\
37 \\
40.8\end{array}$} & \multirow{2}{*}{$\begin{array}{l}S \\
4 \\
2 \cdot 4\end{array}$} & \multirow{2}{*}{$\begin{array}{l}E \\
5 \\
2 \cdot 8\end{array}$} & \\
\hline Pre-preparers & $\begin{array}{l}\text { Observed } \\
\text { Expected }\end{array}$ & & & & \\
\hline Other preparers & $\begin{array}{l}\text { Observed } \\
\text { Expected }\end{array}$ & $\begin{array}{l}558 \\
575 \cdot 4\end{array}$ & $\begin{array}{l}43 \\
29 \cdot 7\end{array}$ & $\begin{array}{l}33 \\
28.9\end{array}$ & $\begin{array}{l}634 \\
634.0\end{array}$ \\
\hline Wet finishers & $\begin{array}{l}\text { Observed } \\
\text { Expected }\end{array}$ & $\begin{array}{l}369 \\
352 \cdot 1\end{array}$ & $\begin{array}{l}13 \\
22 \cdot 4\end{array}$ & $\begin{array}{l}13 \\
20 \cdot 5\end{array}$ & $\begin{array}{l}395 \\
395.0\end{array}$ \\
\hline Other finishers & $\begin{array}{l}\text { Observed } \\
\text { Expected }\end{array}$ & $\begin{array}{l}519 \\
515.3\end{array}$ & $\begin{array}{l}20 \\
25 \cdot 1\end{array}$ & $\begin{array}{l}24 \\
22 \cdot 6\end{array}$ & $\begin{array}{l}563 \\
563.0\end{array}$ \\
\hline Other workers & $\begin{array}{l}\text { Observed } \\
\text { Expected }\end{array}$ & $\begin{array}{l}32 \\
31 \cdot 4\end{array}$ & $\begin{array}{l}2 \\
1.4\end{array}$ & $\overline{1 \cdot 2}$ & $\begin{array}{l}34 \\
34 \cdot 0\end{array}$ \\
\hline
\end{tabular}

*O = no chronic bronchitis; $\mathrm{S}=$ simple $; \mathrm{E}=$ with an exacerbation (see text).

Pre-preparers and other preparers, and other finishers and other workers grouped for $\chi^{2}$ test: $\chi^{2}=18.38 ;$ D.F. $=4 ; 0.01>P>0.001$

usual age of retirement, workers in the oldest age group in each sex were omitted. In view of the small numbers of workers in the various sub-groups to be considered, standardization for 'location of mill' was omitted, and because very few workers in nonpreparing departments had byssinosis the analysis was confined to those in preparing departments.

These considerations apply to this and all subsequent analyses except where stated.

Male workers show no obvious association (Table 8) and female workers show only a weak association (Table 9) between age and byssinosis independent of the effects of smoking habit and the duration of occupation in preparing processes. If all grades of byssinosis (other than 0 ) are combined and the dis- tribution of workers with and without symptoms is compared in the same way, byssinosis in male workers still shows no obvious association with age, and in female workers the weak association appears to be lost. Inspection of the data suggests that in both sexes increasing age of preparers may be associated with some progression in the grade of byssinosis (from $\frac{1}{2}$ to II), but there is no evidence of a consistent change with advancing age in the total proportion of preparers affected by the condition.

Byssinosis and Duration of Employment in Preparing Stages.-Independent of the effects of age and smoking habit there is little evidence of an association between byssinosis grade and the duration of employment in male preparers (Table 10),

\section{TABLE 6}

OBSERVED DISTRIBUTION OF MALE WORKERS BY DYSPNOEA GRADE AND OCCUPATION GROUP, AND THAT EXPECTED ON THE BASIS OF A NULL HYPOTHESIS AFTER STANDARDIZATION FOR AGE, SMOKING HABIT, AND LOCATION OF MILL

\begin{tabular}{|c|c|c|c|c|c|}
\hline \multirow{2}{*}{\multicolumn{2}{|c|}{ Occupation Group }} & \multicolumn{3}{|c|}{ Dyspnoea Grade } & \multirow{3}{*}{$\begin{array}{l}\text { Totals } \\
\begin{array}{l}155 \\
155.0\end{array}\end{array}$} \\
\hline & & \multirow{2}{*}{$\begin{array}{c}I \\
113 \\
130.8\end{array}$} & \multirow{2}{*}{$\begin{array}{l}\text { II } \\
36 \\
21 \cdot 7\end{array}$} & \multirow{2}{*}{$\begin{array}{l}\text { III } \\
6 \\
2 \cdot 5\end{array}$} & \\
\hline Pre-preparers & $\begin{array}{l}\text { Observed } \\
\text { Expected }\end{array}$ & & & & \\
\hline Other preparers & $\begin{array}{l}\text { Observed } \\
\text { Expected }\end{array}$ & $\begin{array}{l}82 \\
83.9\end{array}$ & $\begin{array}{l}16 \\
12.9\end{array}$ & $\overline{1 \cdot 2}$ & $\begin{array}{l}98 \\
98.0\end{array}$ \\
\hline Wet finishers & $\begin{array}{l}\text { Observed } \\
\text { Expected }\end{array}$ & $\begin{array}{l}48 \\
46 \cdot 6\end{array}$ & $\begin{array}{l}5 \\
6.6\end{array}$ & $\begin{array}{l}1 \\
0.9\end{array}$ & $\begin{array}{l}54 \\
54.0\end{array}$ \\
\hline Other finishers & $\begin{array}{l}\text { Observed } \\
\text { Expected }\end{array}$ & $\begin{array}{l}129 \\
123 \cdot 2\end{array}$ & $\begin{array}{l}10 \\
15.9\end{array}$ & $\begin{array}{l}2 \\
1.9\end{array}$ & $\begin{array}{l}141 \\
141 \cdot 0\end{array}$ \\
\hline Other workers & $\begin{array}{l}\text { Observed } \\
\text { Expected }\end{array}$ & $\begin{array}{l}333 \\
329 \cdot 5\end{array}$ & $\begin{array}{l}38 \\
47 \cdot 9\end{array}$ & $\begin{array}{l}4 \\
6 \cdot 6\end{array}$ & $\begin{array}{l}375 \\
375 \cdot 0\end{array}$ \\
\hline
\end{tabular}

N.B. - 33 workers with heart trouble, etc., were omitted (see text) Dyspnoea grades II and III grouped for $x^{2}$ test: $x^{2}=23 \cdot 42$; D.F. $=4 ; \mathrm{P}<0.001$.

TABLE 7

OBSERVED DISTRIBUTION OF FEMALE WORKERS BY DYSPNOEA GRADE AND OCCUPATION GROUP, AND THAT EXPECTED ON THE BASIS OF A NULL HYPOTHESIS, AFTER STANDARDIZATION FOR AGE, SMOKING HABIT, AND LOCATION OF MILL

\begin{tabular}{|c|c|c|c|c|c|}
\hline \multirow{2}{*}{\multicolumn{2}{|c|}{ Occupation Group }} & \multicolumn{3}{|c|}{ Dyspnoea Grade } & \multirow{3}{*}{$\begin{array}{c}\text { Totals } \\
45 \\
45.0\end{array}$} \\
\hline & & \multirow{2}{*}{$\begin{array}{c}\text { I } \\
34 \\
34 \cdot 7\end{array}$} & \multirow{2}{*}{$\begin{array}{l}\text { II } \\
7 \\
9 \cdot 3\end{array}$} & \multirow{2}{*}{$\frac{\text { III }}{4}$} & \\
\hline Pre-preparers & $\begin{array}{l}\text { Observed } \\
\text { Expected }\end{array}$ & & & & \\
\hline Other preparers & $\begin{array}{l}\text { Observed } \\
\text { Expected }\end{array}$ & $\begin{array}{l}453 \\
484 \cdot 3\end{array}$ & $\begin{array}{l}160 \\
130.0\end{array}$ & $\begin{array}{l}12 \\
10 \cdot 7\end{array}$ & $\begin{array}{l}625 \\
625 \cdot 0\end{array}$ \\
\hline Wet finishers & $\begin{array}{l}\text { Observed } \\
\text { Expected }\end{array}$ & $\begin{array}{l}302 \\
299.9\end{array}$ & $\begin{array}{l}79 \\
80.9\end{array}$ & $\begin{array}{l}6 \\
6 \cdot 2\end{array}$ & $\begin{array}{l}387 \\
387 \cdot 0\end{array}$ \\
\hline Other finishers & $\begin{array}{l}\text { Observed } \\
\text { Expected }\end{array}$ & $\begin{array}{l}459 \\
429 \cdot 3\end{array}$ & $\begin{array}{c}90 \\
115 \cdot 3\end{array}$ & $\begin{array}{l}4 \\
8 \cdot 4\end{array}$ & $\begin{array}{l}553 \\
553.0\end{array}$ \\
\hline Other workers & $\begin{array}{l}\text { Observed } \\
\text { Expected }\end{array}$ & $\begin{array}{l}26 \\
25 \cdot 8\end{array}$ & $\begin{array}{l}7 \\
7 \cdot 6\end{array}$ & $\begin{array}{l}1 \\
0.7\end{array}$ & $\begin{array}{l}34 \\
34 \cdot 1\end{array}$ \\
\hline
\end{tabular}

N.B. - 28 workers with heart trouble, etc., were omitted (see text) Dyspnoea grades II and III grouped for $\chi^{2}$ test: $\chi^{2}=18.31$; D.F. $=4 ; 0.01>$ P $>0.001$. 
TABLE 8

OBSERVED DISTRIBUTION OF MALE PREPARERS (35-64 YEARS OF AGE) BY BYSSINOSIS GRADE AND AGE, AND THAT EXPECTED ON THE BASIS OF A NULL HYPOTHESIS, AFTER STANDARDIZATION FOR SMOKING HABIT AND DURATION OF EMPLOYMENT IN FLAX-PREPARING PROCESSES

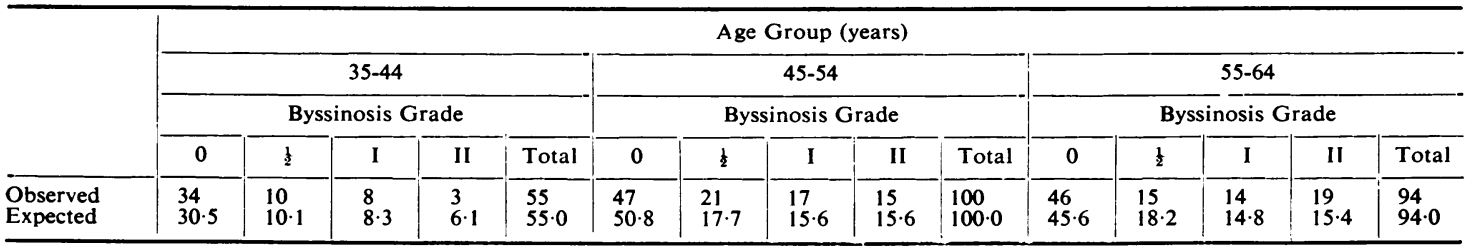

$x^{2}=4.45 ;$ D.F. $=6 ; 0.70>\mathrm{P}>0.50$.

Byssinosis $\frac{1}{2}, \mathrm{I}$ and II grouped: $x^{2}=1 \cdot 50 ;$ D.F. $=2 ; 0.5>\mathrm{P}>0.3$.

TABLE 9

OBSERVED DISTRIBUTION OF FEMALE PREPARERS (35-59 YEARS OF AGE) BY BYSSINOSIS GRADE AND AGE, AND THAT EXPECTED ON THE BASIS OF A NULL HYPOTHESIS, AFTER STANDARDIZATION FOR SMOKING HABIT AND' DURATION OF EMPLOYMENT IN FLAX-PREPARING PROCESSES

\begin{tabular}{|c|c|c|c|c|c|c|c|c|c|c|c|c|c|c|c|}
\hline & \multicolumn{15}{|c|}{ Age Group (years) } \\
\hline & \multicolumn{5}{|c|}{$35-44$} & \multicolumn{5}{|c|}{$45-54$} & \multicolumn{5}{|c|}{$55-59$} \\
\hline & \multicolumn{5}{|c|}{ Byssinosis Grade } & \multicolumn{5}{|c|}{ Byssinosis Grade } & \multicolumn{5}{|c|}{ Byssinosis Grade } \\
\hline & 0 & $\frac{1}{2}$ & I & II & Total & 0 & $\frac{1}{2}$ & I & II & Total & 0 & $\frac{1}{2}$ & I & II & Total \\
\hline $\begin{array}{l}\text { Observed } \\
\text { Expected }\end{array}$ & $\begin{array}{l}181 \\
183 \cdot 1\end{array}$ & $\begin{array}{l}32 \\
31 \cdot 8\end{array}$ & $\begin{array}{l}31 \\
29 \cdot 7\end{array}$ & $\begin{array}{l}16 \\
15.4\end{array}$ & $\begin{array}{l}260 \\
260 \cdot 0\end{array}$ & $\begin{array}{l}190 \\
184 \cdot 3\end{array}$ & $\begin{array}{l}36 \\
30 \cdot 8\end{array}$ & $\begin{array}{l}19 \\
23 \cdot 6\end{array}$ & $\begin{array}{c}7 \\
13 \cdot 3\end{array}$ & 252.0 & $\begin{array}{l}73 \\
76 \cdot 6\end{array}$ & $\begin{array}{c}9 \\
14.4\end{array}$ & $\begin{array}{l}14 \\
10 \cdot 7\end{array}$ & $\begin{array}{c}12 \\
6.3\end{array}$ & $\begin{array}{l}108 \\
108 \cdot 0\end{array}$ \\
\hline
\end{tabular}

$\chi^{2}=13.53$; D.F. $=6 ; 0.05>$ P $>0.02$.

Byssinosis $\frac{1}{2}$, I, and II grouped: $x^{2}=1 \cdot 11 ;$ D.F. $=2 ; 0 \cdot 70>\mathrm{P}>0.50$.

TABLE 10

OBSERVED DISTRIBUTION OF MALE PREPARERS (35-64 YEARS OF AGE), BY BYSSINOSIS GRADE AND DURATION OF EMPLOYMENT IN FLAX-PREPARING PROCESSES, AND THAT EXPECTED ON THE BASIS OF A NULL HYPOTHESIS, AFTER STANDARDIZATION FOR AGE AND SMOKING HABIT

\begin{tabular}{|c|c|c|c|c|c|c|c|c|c|c|c|c|c|c|c|c|c|c|c|c|}
\hline & \multicolumn{20}{|c|}{ Duration of Employment in Flax-preparing Processes (years) } \\
\hline & \multicolumn{5}{|c|}{ Under 15} & \multicolumn{5}{|c|}{$15-24$} & \multicolumn{5}{|c|}{$25-34$} & \multicolumn{5}{|c|}{$35+$} \\
\hline & \multicolumn{5}{|c|}{ Byssinosis Grade } & \multicolumn{5}{|c|}{ Byssinosis Grade } & \multicolumn{5}{|c|}{ Byssinosis Grade } & \multicolumn{5}{|c|}{ Byssinosis Grade } \\
\hline & $\mathbf{0}$ & $\frac{1}{2}$ & I & II & Total & 0 & $\frac{1}{2}$ & I & II & $\overline{\text { Total }}$ & 0 & $\frac{1}{2}$ & I & II & Total & 0 & $\frac{1}{2}$ & $\mathbf{I}$ & II & $\overline{\text { Total }}$ \\
\hline $\begin{array}{l}\text { Observed } \\
\text { Expected }\end{array}$ & $\begin{array}{l}37 \\
27 \cdot 6\end{array}$ & $\begin{array}{l}8 \\
9 \cdot 4\end{array}$ & $\begin{array}{l}5 \\
8 \cdot 0\end{array}$ & $\begin{array}{l}2 \\
7.0\end{array}$ & $\begin{array}{l}52 \\
52.0\end{array}$ & $\begin{array}{l}26 \\
29 \cdot 7\end{array}$ & $\begin{array}{l}12 \\
11 \cdot 1\end{array}$ & $\begin{array}{c}10 \\
8 \cdot 6\end{array}$ & $\begin{array}{l}8 \\
6 \cdot 6\end{array}$ & $\begin{array}{l}56 \\
56 \cdot 0\end{array}$ & $\begin{array}{l}32 \\
31.9\end{array}$ & $\begin{array}{l}10 \\
12 \cdot 1\end{array}$ & $\begin{array}{l}11 \\
10 \cdot 6\end{array}$ & $\begin{array}{c}11 \\
9 \cdot 4\end{array}$ & $\begin{array}{l}64 \\
64 \cdot 0\end{array}$ & $\begin{array}{l}32 \\
37 \cdot 8\end{array}$ & $\begin{array}{l}16 \\
13 \cdot 3\end{array}$ & $\begin{array}{l}13 \\
11.9\end{array}$ & $\begin{array}{l}16 \\
14.0\end{array}$ & $\begin{array}{l}77 \\
77.0\end{array}$ \\
\hline
\end{tabular}

$x^{2}=11.62 ;$ D.F. $=9 ; 0.30>P>0.20$.

Byssinosis $\frac{1}{2}$, I, and II grouped: $\chi^{2}=9.53 ;$ D.F. $=3 ; 0.05>$ P $>0.02$.

TABLE 11

OBSERVED DISTRIBUTION OF FEMALE PREPARERS (35-59 YEARS OF AGE) BY BYSSINOSIS GRADE AND DURATION OF EMPLOYMENT IN FLAX-PREPARING PROCESSES, AND THAT EXPECTED ON THE BASIS OF A NULL HYPOTHESIS, AFTER STANDARDIZATION FOR AGE AND SMOKING HABIT

\begin{tabular}{|c|c|c|c|c|c|c|c|c|c|c|c|c|c|c|c|c|c|c|c|c|}
\hline & \multicolumn{20}{|c|}{ Duration of Employment in Flax-preparing Processes (years) } \\
\hline & \multicolumn{5}{|c|}{ Under 15} & \multicolumn{5}{|c|}{$15-24$} & \multicolumn{5}{|c|}{$25-34$} & \multicolumn{5}{|c|}{$35+$} \\
\hline & \multicolumn{5}{|c|}{ Byssinosis Grade } & \multicolumn{5}{|c|}{ Byssinosis Grade } & \multicolumn{5}{|c|}{ Byssinosis Grade } & \multicolumn{5}{|c|}{ Byssinosis Grade } \\
\hline & 0 & $\frac{1}{2}$ & I & II & Total & 0 & $\frac{1}{2}$ & I & II & Total & 0 & $\frac{1}{2}$ & I & II & Total & 0 & $\frac{1}{2}$ & I & II & Total \\
\hline $\begin{array}{l}\text { Observed } \\
\text { Expected }\end{array}$ & \begin{tabular}{|l|}
205 \\
$181 \cdot 2$ \\
\end{tabular} & $\begin{array}{l}19 \\
32 \cdot 7\end{array}$ & $\begin{array}{l}16 \\
27 \cdot 4\end{array}$ & $\begin{array}{l}16 \\
14.7\end{array}$ & \begin{tabular}{|l|}
256 \\
$256 \cdot 0$
\end{tabular} & $\mid$\begin{tabular}{l|}
100 \\
$111 \cdot 7$
\end{tabular} & $\begin{array}{l}22 \\
20.6\end{array}$ & $\begin{array}{l}28 \\
16.9\end{array}$ & $\begin{array}{l}8 \\
8 \cdot 8\end{array}$ & $\mid$\begin{tabular}{|l|}
158 \\
$158 \cdot 0$
\end{tabular} & $\begin{array}{l}94 \\
96.9\end{array}$ & $\begin{array}{l}22 \\
16 \cdot 3\end{array}$ & $\begin{array}{l}10 \\
12.4\end{array}$ & $\begin{array}{l}6 \\
6 \cdot 4\end{array}$ & $\mid$\begin{tabular}{|l|}
132 \\
$132 \cdot 0$
\end{tabular} & $\begin{array}{l}45 \\
54 \cdot 1\end{array}$ & $\begin{array}{c}14 \\
7 \cdot 4\end{array}$ & $\begin{array}{c}10 \\
7.4\end{array}$ & $\begin{array}{l}5 \\
5 \cdot 1\end{array}$ & $\begin{array}{l}74 \\
74.0\end{array}$ \\
\hline
\end{tabular}

$x^{2}=38.93 ;$ D.F. $=9$; P $<0.001$.

Byssinosis $\frac{1}{2}$, I, and II grouped: $\chi^{2}=19.90 ;$ D.F. $=3$; P $<0.001$. 
but there is evidence of an association in female preparers (Table 11). If all grades of byssinosis (other than 0) are combined, the data for workers of each sex show an association which appears to be significant. This suggests that independent of age and in both sexes the proportion of preparers with byssinosis increases as the duration of employment in flax-preparing processes increases. Inspection of the data confirms that in each sex there is a deficiency in the total number of preparers with less than 15 years' employment who had byssinosis compared with the number expected, but a relative excess in those who had worked for more than 35 years in preparing processes. However, this increase in prevalence with the duration of employment is not consistent, nor is there any evidence of a consistent progression in the grade of byssinosis in affected preparers with an increasing duration of employment.

Byssinosis and Smoking Habit.-Male preparers do not appear to show a significant association between byssinosis grade and smoking habit (Table 12), though if all grades of byssinosis (other than 0 ) are combined, there appears to be a significant association between smoking habit and the presence, or absence, of byssinosis. Female preparers show a marked association between smoking habit and byssinosis grade (Table 13). In both sexes, but to a more marked degree in women, the observed numbers of affected workers are greater in smokers, and smaller in non-smokers, than expected. The data for exsmokers are too few in women for confident interpretation but in men the differences they show between the observed and expected numbers appear to be similar in size to those of male non-smokers.

Byssinosis and Sex.-Because the amount of tobacco smoked by smokers of each sex is likely to

TABLE 12

OBSERVED DISTRIBUTION OF MALE PREPARERS (35-64 YEARS OF AGE) BY BYSSINOSIS GRADE AND SMOKING HABIT, AND THAT EXPECTED ON THE BASIS OF A NULL HYPOTHESIS, AFTER STANDARDIZATION FOR AGE AND DURATION OF EMPLOYMENT IN FLAX-PREPARING PROCESSES

\begin{tabular}{|c|c|c|c|c|c|c|}
\hline \multirow{2}{*}{\multicolumn{2}{|c|}{ Smoking Habit }} & \multicolumn{4}{|c|}{ Byssinosis Grade } & \multirow{3}{*}{$\begin{array}{l}\text { Totals } \\
35 \\
35.0\end{array}$} \\
\hline & & \multirow{2}{*}{\begin{tabular}{c}
\multicolumn{1}{c}{0} \\
26 \\
19.6
\end{tabular}} & \multirow{2}{*}{$\begin{array}{l}\frac{1}{2} \\
3 \\
5 \cdot 5\end{array}$} & \multirow{2}{*}{$\begin{array}{l}I \\
5 \\
5.0\end{array}$} & \multirow{2}{*}{ 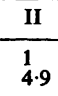 } & \\
\hline Non-smokers & $\begin{array}{l}\text { Observed } \\
\text { Expected }\end{array}$ & & & & & \\
\hline Smokers & $\begin{array}{l}\text { Observed } \\
\text { Expected }\end{array}$ & $\begin{array}{l}79 \\
87 \cdot 7\end{array}$ & $\begin{array}{l}37 \\
33 \cdot 8\end{array}$ & $\begin{array}{l}28 \\
27 \cdot 7\end{array}$ & $\begin{array}{l}31 \\
25 \cdot 8\end{array}$ & $\begin{array}{l}175 \\
175.0\end{array}$ \\
\hline Ex-smokers & $\begin{array}{l}\text { Observed } \\
\text { Expected }\end{array}$ & $\begin{array}{l}22 \\
19 \cdot 7\end{array}$ & $\begin{array}{l}6 \\
6 \cdot 7\end{array}$ & $\begin{array}{l}6 \\
6 \cdot 3\end{array}$ & $\begin{array}{l}5 \\
6 \cdot 3\end{array}$ & $\begin{array}{l}39 \\
39.0\end{array}$ \\
\hline
\end{tabular}

Non-smokers and ex-smokers grouped for $\chi^{2}$ test: $x^{2}=7 \cdot 46$ D.F. $=3 ; 0.10>$ P $>0.05$

Non-smokers and ex-smokers, and byssinosis grades $\frac{1}{2}$, I, and II grouped for $x^{2}$ test: $x^{2}=6.94 ;$ D.F. $=2 ; 0.05>P>0.02$.
TABLE 13

OBSERVED DISTRIBUTION OF FEMALE PREPARERS (35-59 YEARS OF AGE) BY BYSSINOSIS GRADE AND SMOKING HABIT, AND THAT EXPECTED ON THE BASIS OF A NULL HYPOTHESIS, AFTER STANDARDIZATION FOR AGE AND DURATION OF EMPLOYMENT IN FLAX-PREPARING PROCESSES

\begin{tabular}{|c|c|c|c|c|c|c|}
\hline \multirow{2}{*}{\multicolumn{2}{|c|}{ Smoking Habit }} & \multicolumn{4}{|c|}{ Byssinosis Grade } & \multirow{3}{*}{\begin{tabular}{|l} 
Totals \\
410 \\
$410 \cdot 0$
\end{tabular}} \\
\hline & & \multirow{2}{*}{$\begin{array}{c}0 \\
317 \\
292.9\end{array}$} & \multirow{2}{*}{$\begin{array}{c}\frac{1}{2} \\
39 \\
52 \cdot 3\end{array}$} & \multirow{2}{*}{\begin{tabular}{l}
\multicolumn{1}{c}{$I$} \\
$31 \cdot 9$
\end{tabular}} & \multirow{2}{*}{$\begin{array}{l}\text { II } \\
19 \\
22 \cdot 9\end{array}$} & \\
\hline Non-smokers & $\begin{array}{l}\text { Observed } \\
\text { Expected }\end{array}$ & & & & & \\
\hline Smokers & $\begin{array}{l}\text { Observed } \\
\text { Expected }\end{array}$ & $\begin{array}{l}113 \\
139.0\end{array}$ & $\begin{array}{l}36 \\
23.0\end{array}$ & $\begin{array}{l}29 \\
20.7\end{array}$ & $\begin{array}{l}16 \\
11 \cdot 3\end{array}$ & $\begin{array}{l}194 \\
194.0\end{array}$ \\
\hline Ex-smokers & $\begin{array}{l}\text { Observed } \\
\text { Expected }\end{array}$ & $\begin{array}{l}14 \\
12 \cdot 1\end{array}$ & $\begin{array}{l}2 \\
1 \cdot 8\end{array}$ & $\overrightarrow{1 \cdot 3}$ & $\overrightarrow{0.8}$ & $\begin{array}{l}16 \\
16.0\end{array}$ \\
\hline
\end{tabular}

Ex-smokers and non-smokers grouped for $x^{2}$ test: $x^{2}=25.49$; D.F. $=3 ; \mathrm{P}<0.001$.

have been very different, the examination of the difference in prevalerce of byssinosis in the two sexes was first made within preparers of each smoking habit separately. This showed that independent of the effects of age and the duration of employment in preparing stages, only very small differences, which are probably not significant, occur in the distributions of byssinosis in the two sexes and those expected on the null hypothesis, and this is also true for men and women of all smoking habits combined (Table 14).

TABLE 14

OBSERVED DISTRIBUTION OF MALE PREPARERS (AGED 35-64) AND FEMALE PREPARERS (AGED 35-59) BY BYSSINOSIS GRADE AND SMOKING HABIT, AND THAT EXPECTED ON THE BASIS OF A NULL HYPOTHESIS, AFTER STANDARDIZATION FOR AGE AND DURATION OF EMPLOYMENT IN FLAX-PREPARING PROCESSES

\begin{tabular}{|c|c|c|c|c|c|c|c|}
\hline \multirow{2}{*}{$\underset{\text { Habit }}{\text { Smoking }}$} & \multirow{2}{*}{ Sex } & & \multicolumn{4}{|c|}{ Byssinosis Grade } & \multirow{2}{*}{ Totals } \\
\hline & & & 0 & $\frac{1}{2}$ & I & II & \\
\hline \multirow{2}{*}{ Non-smokers } & $\mathbf{M}$ & $\begin{array}{l}\text { Observed } \\
\text { Expected }\end{array}$ & $\begin{array}{l}26 \\
25 \cdot 6\end{array}$ & $\begin{array}{l}3 \\
4 \cdot 2\end{array}$ & $\begin{array}{l}5 \\
3.6\end{array}$ & $\stackrel{1}{1 \cdot 7}$ & $\begin{array}{l}35 \\
35 \cdot 1\end{array}$ \\
\hline & $\mathbf{F}$ & $\begin{array}{l}\text { Observed } \\
\text { Expected }\end{array}$ & $\begin{array}{l}317 \\
317 \cdot 5\end{array}$ & $\begin{array}{l}39 \\
37 \cdot 8\end{array}$ & $\begin{array}{l}35 \\
36 \cdot 4\end{array}$ & $\begin{array}{l}19 \\
17 \cdot 3\end{array}$ & $\begin{array}{l}410 \\
410 \cdot 0\end{array}$ \\
\hline \multirow{2}{*}{ Smokers } & $\mathbf{M}$ & $\begin{array}{l}\text { Observed } \\
\text { Expected }\end{array}$ & $\begin{array}{l}79 \\
79 \cdot 5\end{array}$ & $\begin{array}{l}37 \\
38 \cdot 4\end{array}$ & $\begin{array}{l}28 \\
29 \cdot 7\end{array}$ & $\begin{array}{l}31 \\
27 \cdot 4\end{array}$ & $\begin{array}{l}175 \\
175 \cdot 0\end{array}$ \\
\hline & $\mathbf{F}$ & $\begin{array}{l}\text { Observed } \\
\text { Expected }\end{array}$ & $\begin{array}{l}113 \\
112.5\end{array}$ & $\begin{array}{l}36 \\
34 \cdot 6\end{array}$ & $\begin{array}{l}29 \\
27 \cdot 3\end{array}$ & $\begin{array}{l}16 \\
19 \cdot 6\end{array}$ & $\begin{array}{l}194 \\
194.0\end{array}$ \\
\hline \multirow{2}{*}{ Ex-smokers } & $\mathbf{M}$ & $\begin{array}{l}\text { Observed } \\
\text { Expected }\end{array}$ & $\begin{array}{l}22 \\
23 \cdot 4\end{array}$ & $\begin{array}{l}6 \\
5 \cdot 4\end{array}$ & $\stackrel{6}{5 \cdot 1}$ & $\begin{array}{l}5 \\
5 \cdot 0\end{array}$ & $\begin{array}{l}39 \\
38 \cdot 9\end{array}$ \\
\hline & $\mathbf{F}$ & $\begin{array}{l}\text { Observed } \\
\text { Expected }\end{array}$ & $\begin{array}{l}14 \\
12 \cdot 6\end{array}$ & $\begin{array}{l}2 \\
2 \cdot 6\end{array}$ & $\overline{0.8}$ & 二 & $\begin{array}{l}16 \\
16.0\end{array}$ \\
\hline
\end{tabular}

Non-smokers: Byssinosis grades I and II grouped for $\chi^{2}$ test $\chi^{2}=0.46 ;$ D.F. $=2 ; 0.80>P>0.70$.

Smokers: $\chi^{2}=1.45 ;$ D.F. $=3 ; 0.70>\mathrm{P}>0.50$.

Ex-smokers: Byssinosis grades $\frac{1}{2}$, I, and II grouped for $\chi^{2}$ test : $x^{2}=0.96 ;$ D.F. $=1 ; 0.50>$ P $>0.30$.

All men and all women: $x^{2}=0.63 ;$ D.F. $=3 ; 0.90>P>0.80$.

Byssinosis and Chronic Bronchitis.-Tables 15 and 16 show that in both sexes there is a marked association between the distributions of workers by bys- 
sinosis grade and chronic bronchitis grade in preparers of each sex. There is a fairly consistent trend in each sex, the observed numbers of workers with symptoms of both conditions being higher than expected on the null hypothesis, and in most subgroups the more severe these symptoms, the greater the relative excess of observed over expected.

TABLE 15

OBSERVED DISTRIBUTION OF MALE PREPARERS (OVER 35 YEARS OF AGE) BY BYSSINOSIS GRADE AND CHRONIC BRONCHITIS GRADE, AND THAT EXPECTED ON THE BASIS OF A NULL HYPOTHESIS, AFTER

STANDARDIZATION FOR AGE AND SMOKING HABIT

\begin{tabular}{|c|c|c|c|c|c|c|}
\hline & \multirow{2}{*}{$\begin{array}{l}\text { Chronic } \\
\text { Bronchitis } \\
\text { Grade* }\end{array}$} & \multicolumn{4}{|c|}{ Byssinosis Grade } & \multirow{2}{*}{ Totals } \\
\hline & & 0 & $\frac{1}{2}$ & I & II & \\
\hline $\mathbf{O}$ & $\begin{array}{l}\text { Observed } \\
\text { Expected }\end{array}$ & $\begin{array}{c}106 \\
93 \cdot 8\end{array}$ & $\begin{array}{l}27 \\
30 \cdot 1\end{array}$ & $\begin{array}{l}29 \\
25.9\end{array}$ & $\begin{array}{l}11 \\
23 \cdot 2\end{array}$ & $\begin{array}{l}173 \\
172 \cdot 9\end{array}$ \\
\hline $\mathbf{S}$ & $\begin{array}{l}\text { Observed } \\
\text { Expected }\end{array}$ & $\begin{array}{l}19 \\
26 \cdot 4\end{array}$ & $\begin{array}{l}13 \\
11.0\end{array}$ & $\begin{array}{l}8 \\
9 \cdot 0\end{array}$ & 16 & $\begin{array}{l}56 \\
56 \cdot 0\end{array}$ \\
\hline $\mathbf{E}$ & $\begin{array}{l}\text { Observed } \\
\text { Expected }\end{array}$ & $\begin{array}{l}12 \\
16.8\end{array}$ & $\begin{array}{l}7 \\
5.9\end{array}$ & $\begin{array}{l}3 \\
5 \cdot 1\end{array}$ & 11 & $\begin{array}{l}33 \\
33 \cdot 0\end{array}$ \\
\hline
\end{tabular}

$* \mathrm{O}=$ nil; $\mathrm{S}=$ simple; $\mathrm{E}=$ with a recent exacerbation.

$\chi^{2}=24.23 ;$ D.F. $=6$; P $<0.001$.

TABLE 16

OBSERVED DISTRIBUTION OF FEMALE PREPARERS (OVER 35 YEARS OF AGE) BY BYSSINOSIS GRADE AND CHRONIC BRONCHITIS GRADE, AND THAT EXPECTED ON THE BASIS OF A NULL'HYPOTHESIS, AFTER STANDARDIZATION FOR AGE AND SMOKING HABIT

\begin{tabular}{|c|c|c|c|c|c|c|}
\hline & \multirow{2}{*}{$\begin{array}{l}\text { Chronic } \\
\text { Bronchitis } \\
\text { Grade* }^{*}\end{array}$} & \multicolumn{4}{|c|}{ Byssinosis Grade } & \multirow{2}{*}{ Totals } \\
\hline & & 0 & $\frac{1}{2}$ & I & II & \\
\hline O & $\begin{array}{l}\text { Observed } \\
\text { Expected }\end{array}$ & $\begin{array}{l}461 \\
439.0\end{array}$ & $\begin{array}{l}71 \\
69 \cdot 4\end{array}$ & $\begin{array}{l}48 \\
54.9\end{array}$ & $\begin{array}{l}15 \\
31 \cdot 7\end{array}$ & $\begin{array}{l}595 \\
595.0\end{array}$ \\
\hline $\mathbf{S}$ & $\begin{array}{l}\text { Observed } \\
\text { Expected }\end{array}$ & $\begin{array}{l}22 \\
33.0\end{array}$ & $\begin{array}{l}7 \\
6 \cdot 2\end{array}$ & $\begin{array}{l}8 \\
4.9\end{array}$ & $\begin{array}{c}10 \\
2 \cdot 8\end{array}$ & $\begin{array}{l}47 \\
47.0\end{array}$ \\
\hline $\mathbf{E}$ & $\begin{array}{l}\text { Observed } \\
\text { Expected }\end{array}$ & $\begin{array}{l}15 \\
26.0\end{array}$ & $\begin{array}{l}3 \\
5 \cdot 4\end{array}$ & $\begin{array}{l}8 \\
4 \cdot 1\end{array}$ & ${ }_{2 \cdot 5}^{12}$ & $\begin{array}{l}38 \\
38 \cdot 0\end{array}$ \\
\hline
\end{tabular}

*O = nil; $\mathrm{S}=$ simple; $\mathrm{E}=$ with a recent exacerbation.

Byssinosis grades I and II grouped: $x^{2}=57 \cdot 43$; D.F. $=4$; P $<$ 0.001 .

Byssinosis and Dyspnoea.-Tables 17 and 18 show that there is a marked association between the distribution of workers by byssinosis grade and dyspnoea grade. Expected distributions have been standardized for age and smoking habit but not for the duration of employment or the location of the mill. In each sex the numbers of preparers with both advanced byssinosis and dyspnoea (grades II and III) are, in most sub-groups, larger than expected on the null hypothesis.

\section{Discussion}

The use of tests of significance in an observational study such as the one presented here, in contrast
TABLE 17

OBSERVED DISTRIBUTION OF MALE PREPARERS (AGED 35-64 YEARS) IN FLAX MILLS BY BYSSINOSIS GRADE AND DYSPNOEA GRADE, AND THAT EXPECTED ON THE BASIS OF A NULL HYPOTHESIS, AFTER STANDARDIZA-
TION FOR AGE AND SMOKING HABIT

\begin{tabular}{|c|c|c|c|c|c|c|}
\hline \multirow{2}{*}{\multicolumn{2}{|c|}{ Dyspnoea Grade }} & \multicolumn{4}{|c|}{ Byssinosis Grade } & \multirow{3}{*}{$\begin{array}{l}\text { Totals } \\
185 \\
185.0\end{array}$} \\
\hline & & \multirow{2}{*}{$\begin{array}{c}0 \\
100 \\
98.4\end{array}$} & \multirow{2}{*}{$\begin{array}{l}\frac{1}{2} \\
37 \\
29 \cdot 6\end{array}$} & \multirow{2}{*}{\begin{tabular}{l}
\multicolumn{1}{c}{ I } \\
30 \\
28.7
\end{tabular}} & \multirow{2}{*}{$\begin{array}{l}\text { II } \\
18 \\
28 \cdot 3\end{array}$} & \\
\hline I & $\begin{array}{l}\text { Observed } \\
\text { Expected }\end{array}$ & & & & & \\
\hline II & $\begin{array}{l}\text { Observed } \\
\text { Expected }\end{array}$ & $\begin{array}{l}20 \\
22 \cdot 4\end{array}$ & $\begin{array}{l}1 \\
7 \cdot 6\end{array}$ & $\begin{array}{l}6 \\
6 \cdot 3\end{array}$ & ${ }_{7.7}^{17}$ & $\begin{array}{l}44 \\
44.0\end{array}$ \\
\hline 10 & $\begin{array}{l}\text { Observed } \\
\text { Expected }\end{array}$ & $\stackrel{4}{3} \cdot 2$ & $\overline{0.8}$ & $\overline{1.0}$ & $\begin{array}{l}2 \\
1.0\end{array}$ & $\begin{array}{l}6 \\
6 \cdot 0\end{array}$ \\
\hline
\end{tabular}

N.B.-14 workers with heart trouble, etc., were omitted (see text). Dyspnoea grades II and III grouped for $x^{2}$ test: $\chi^{2}=24.58$; D.F. $=3 ;$ P $<0.001$.

- TABLE 18

OBSERVED DISTRIBUTION OF FEMALE PREPARERS (AGED 35-59 YEARS) IN FLAX MILLS BY BYSSINOSIS GRADE AND DYSPNOEA GRADE, AND THAT EXPECTED ON THE BASIS OF A NULL HYPOTHESIS, AFTER STANDARDIZATION FOR AGE AND SMOKING HABIT

\begin{tabular}{|c|c|c|c|c|c|c|}
\hline \multirow{2}{*}{\multicolumn{2}{|c|}{ Dyspnoea Grade }} & \multicolumn{4}{|c|}{ Byssinosis Grade } & \multirow{3}{*}{$\begin{array}{l}\text { Totals } \\
\begin{array}{l}454 \\
453.9\end{array}\end{array}$} \\
\hline & & \multirow{2}{*}{$\begin{array}{c}0 \\
352 \\
328 \cdot 6\end{array}$} & \multirow{2}{*}{\begin{tabular}{l}
\multicolumn{1}{c}{$\frac{1}{2}$} \\
58 \\
54.5
\end{tabular}} & \multirow{2}{*}{$\begin{array}{l}I \\
38 \\
45 \cdot 6\end{array}$} & \multirow{2}{*}{$\frac{\text { II }}{\stackrel{6}{25 \cdot 2}}$} & \\
\hline I & $\begin{array}{l}\text { Observed } \\
\text { Expected }\end{array}$ & & & & & \\
\hline II & $\begin{array}{l}\text { Observed } \\
\text { Expected }\end{array}$ & $\begin{array}{c}84 \\
100 \cdot 7\end{array}$ & $\begin{array}{l}15 \\
17.6\end{array}$ & $\begin{array}{l}20 \\
14.9\end{array}$ & $\begin{array}{l}23 \\
8.9\end{array}$ & $\begin{array}{l}142 \\
142 \cdot 1\end{array}$ \\
\hline III & $\begin{array}{l}\text { Observed } \\
\text { Expected }\end{array}$ & $\begin{array}{c}4 \\
10 \cdot 7\end{array}$ & 1.9 & $\begin{array}{l}4 \\
1.5\end{array}$ & $\begin{array}{l}6 \\
0.9\end{array}$ & $\begin{array}{l}15 \\
15.0\end{array}$ \\
\hline
\end{tabular}

N.B.-Nine workers with heart trouble, etc., were omitted (see text). Dyspnoea grades II and III grouped for $\chi^{2}$ test: $\chi^{2}=65 \cdot 19$; D.F. $=3 ;$ P $<0.001$.

Byssinosis grades $\frac{1}{2}$, I and II grouped for $\chi^{2}$ test: $\chi^{2}=30 \cdot 31$; D.F. $=2 ; \mathrm{P}<0.001$.

with a truly experimental study, requires some justification. Their use requires the testing of null hypotheses, and these in turn usually imply that the distribution of subjects by the various attributes of relevance is random, and that any disturbance of this randomness which is detected by a test of significance may be attributed with reasonable confidence to the effect of the factor under examination. Such an assumption is not always entirely reasonable, since if there is a real association between any of the relevant factors, some degree of selection or selective change in the distribution of workers by these factors may occur. For example, in the population on which the present study is based, it is not unreasonable to suppose that applicants for employment in the mills who smoke may, if a choice is possible, select a job where dust exposure is minimal. Furthermore, workers who smoke and who develop respiratory symptoms may either reduce their consumption of tobacco or cease to smoke altogether. Other similar modes of selection are known to have affected the 
present population. For example, workers with respiratory symptoms are known to have left the industry to a greater extent than workers not so affected (Elwood, 1965). In such a situation the use of a null hypothesis is therefore strictly inappropriate. Nevertheless we have used a null hypothesis as a basis for our analysis as this seems to be the best available working hypothesis for the study, and furthermore, as far as can be judged, any bias caused by its use is likely to have led to an underestimation of the strength of the associations examined. We therefore feel that the following conclusions are justified.

There is a strong association between exposure to flax dust and byssinosis, and the comparative infrequency of this condition in those who worked in the less dusty, non-preparing processes, compared with those who worked in the dusty preparing processes, suggests that there is a direct relationship between the level of airborne dust in the working environment and the prevalence of byssinosis. This relationship is examined in more detail elsewhere (Elwood and McAulay, 1965), but it appears that prepreparers, who handle the fibres before or during the initial cleaning processes, and who consequently are exposed to relatively high levels of airborne dust, have a higher prevalence of byssinosis than have preparers who are exposed to lower levels of dust, and these latter have a higher prevalence than workers in dry finishing rooms. Wet spinners and wet polishers are the only large occupational group in flax mills who appear not to be at serious risk of developing the condition, and this is the only group of workers who appear to be consistently exposed to no flax dust or at most to very low levels.

Certainly byssinosis can occur in those who handle dry flax yarn, and levels of airborne dust in some of the rooms in which such persons worked were found to be higher than in some of the preparing rooms (McAulay et al., 1965). These findings in the flax industry differ therefore from those reported by Roach and Schilling (1960) in the cotton industry, since only workers in the early cotton-preparing stages appeared to be at serious risk of developing byssinosis.

The absence of marked associations between byssinosis and age and between byssinosis and duration of employment is unexpected. However, workers in an industry represent a 'survivor population' (Schilling, 1960), and the picture found here could largely be explained if workers affected by respiratory symptoms had left the mills studied. Certainly, selection in this way of workers who leave is known to have occurred in the industry (Elwood, 1965) though whether or not this took place to an extent sufficient to be the sole explanation is un- known. However, the data give some evidence of a progression in the severity of symptoms with an increase in age of the affected workers and of an increase in the proportion affected with an increase in the duration of employment of workers in preparing stages of the industry, but these trends are weak and their interrelation requires further study.

The prevalence of both chronic bronchitis and dyspnoea appears to follow the same pattern as that of byssinosis within the occupation groups. Workers in preparing processes had a much higher prevalence of these symptoms than those in non-preparing processes, and there was evidence of a fall in prevalence from pre-preparers, who are exposed to the highest levels of flax dust, to wet spinners, who are exposed to no or very little flax dust (McAulay et al., 1965). In view of the similarity of these trends, the interrelations of byssinosis with chronic bronchitis and with dyspnoea are of considerable interest, and it appears from the present data that these symptoms are closely related; workers who had byssinosis were found to be much more likely also to have chronic bronchitis and dyspnoea than workers who did not have byssinosis.

The similarity in the clinical picture of advanced byssinosis and chronic bronchitis has been stressed by many writers (Kay, 1831; Prausnitz, 1936; Schilling, 1956; Smiley, 1961). Byssinosis may therefore simply represent, in the early stages, a relatively acute and reversible effect of certain vegetable textile dusts on the respiratory system of exposed workers. It is of interest that small falls in respiratory function have been demonstrated within a day in nonbyssinotic workers exposed to cotton dust (McKerrow, McDermott, Gilson, and Schilling, 1958; Batawi, Schilling, Valić, and Walford, 1964) and to flax dust (Bouhuys et al., 1961) though none of these changes are, in the context of the work published, statistically significant. These effects of textile dusts and the resultant symptoms may be caused by smooth muscle constricting substances such as those demonstrated by Davenport and Paton (1962) and by Nicholls (1962), and it seems not unreasonable to suppose that while such substances may have an effect in most or in all exposed persons, this may be greater, or more noticeable, in workers whose respiratory tract is irritated or whose lung function is impaired by conditions such as chronic bronchitis.

It also seems likely that in addition to this acute and specific effect, textile dusts may have a chronic non-specific effect on the respiratory system of exposed workers and may bear an aetiological relationship to chronic bronchitis, which is similar to that of other dusts (Higgins, Cochrane, Gilson, and Wood, 1959; Higgins, Oldham, Cochrane, and 
Gilson, 1956) and other pollutants such as tobacco smoke (Doll and Hill, 1956). Certainly one would not expect the distributions of byssinosis and of chronic bronchitis in a group of textile workers to be co-incident, since the distribution of persons with chronic bronchitis is, by the use of a definition such as the one used here, truncated, only those persons who have had symptoms of a certain severity and duration being so diagnosed, whereas the distribution of persons with byssinosis is not so limited. Nor is the absence of significant differences in the prevalence of byssinosis in male and female workers unexpected, since the groups examined here had been exposed to relatively high levels of flax dust, and the comparisons made between workers of each sex are independent of differences in age, duration of employment, and smoking habit.

This study could not have been completed without considerable help from several organizations and many individuals. The Council of the Flax Spinners' Association Ltd., the textile section of the Transport and General Workers' Union, and the managers, welfare, and medical staff, and workers in the mills deserve our thanks for their help. Professor E. A. Cheeseman gave constant and invaluable statistical advice, and Dr. J. A. Smiley, O.B.E., and Dr. P. Froggatt gave frequent encouragement and help. Mrs. J. Adams assisted in the field work of the study, Mrs. J. McCabe, Mrs. L. McCreight, and Miss E. Jackson conducted the mechanical processing of the data, Miss T. Pitt and Mrs. E. Kingston assisted with the analysis, and Miss J. Broderick was responsible for all the secretarial work.

The survey was undertaken at the request of the Ministry of Labour and National Insurance of the Government of Northern Ireland which made a grant towards the cost of the survey.

\section{REFERENCES}

Batawi, M. A. El, Schilling, R. S. F., Valić, F., and Walford, J. (1964). Brit. J. industr. Med., 21, 13.

Bouhuys, A., Van Duyn, J., and Van Lennep, H. J. (1961). Arch.

Carey, G. C. R., Merrett, J. D., Elwood, P. C., Pemberton, J., and McAulay, I. R. (1965). Brit. J. industr. Med. In press.

Davenport, A., and Paton, W. D. M. (1962). Brit. J. industr. Med., $19,19$.

Doll, R., and Hill, A. B. (1956). Brit. med. J., 2, 1071.

Elwood, P. C. (1965). Brit. J. industr. Med., 22, 38.

- and McAulay, I. R. (1965). In preparation.

Fletcher, C. M., and Tinker, C. M. (1961). Brit. med. J., 1, 1491.

Higgins, I. T. T., and Cochrane, A. L. (1961). Brit. J. industr. Med. 18,93.

18, Gilson, J. C., and Wood, C. H. (1959). Ibid., 16, 255.

Oldham, P. D., Cochrane, A. L., and Gilson, J. C. (1956). Brit. med. J., 2, 904.

Kay, J. P. (1831). North Engl. med. surg. J., 1, 348.

Logan, J. S. (1959). Ulster med. J., 28, 164.

McAulay, I. R., Carey, G. C. R., Merrett, J. D., Elwood, P. C., and Pemberton, J. (1965). In preparation.

McKerrow, C. B., McDermott, M., Gilson, J. C., and Schilling, R. S. F. (1958). Brit. J. industr. Med., 15, 75.

Mair, A., Smith, D. H., Wilson, W. A., and Lockhart, W. (1960). Ibid., 17, 272 .

Malcolm, A. G. (1856). J.R. statist. Soc., 19, 170.

Medical Research Council (1960a). Questionnaire on Respiratory Symptoms.

(1960b). Instructions for the use of the Questionnaire on Respiratory Symptoms.

Nicholls, P. J. (1962). Brit. J. industr. Med., 19, 33.

Prausnitz, C. (1936). Investigations on Respiratory Dust Disease in Operatives in the Cotton Industry. Spec. Rep. Ser. med. Res. Coun. (Lond.), No. 212.

Purdon, C. D. (1873). The Mortality of Flax Mill and Factory Workers as compared with Other Classes of the Community. Adair, Belfast.

(1875). Longevity of Flax Mill and Factory Operatives. Adair, Belfast.

Belfast.
(1877). The Sanitary State of the Belfast Factory District during the Ten Years (1864 to 1873) under Various Aspects. Adair,

Belfast.
Ramazzini, B. (1705). De Morbis Artificium Diatriba, translated by R. James (1746). London and York.

Roach, S. A., and Schilling, R. S. F. (1960). Brit. J. industr. Med., 17, 1 .

Schilling, R. S. F. (1956), Lancet, 2, 261 and 319.

(1960). Modern Trends in Occupational Health. Butterworth, London.

Smiley, J. A. (1951). Brit. J. industr. Med., 8, 265.

(1961). Ibid., 18, 1.

Thackrah, C. T. (1832). The Effects of Arts, Trades, and Professions, and of Civic States and Habits of Living on Health and Longevity, 2nd ed. Longman, Rees, Orme, Brown, Green, and Longman, London. 